\title{
To Have Good Taste in the Mood for Love
}

\author{
Zhengshun Han \\ Wuhan Textile University \\ Wuhan, China 430073
}

\begin{abstract}
The American blockbuster Six Days and Seven Nights is a beautifully-conceived, well-performed and artistically- designed moving movie. It tells the story of a would- be couple Roben Monroe \& her boyfriend Frank who decided to go on a long-awaited holiday in Hawaii in an attempt to increase the romance in their relationship and to have fun, love and happiness. However, to their surprise, right after their arrival at the destination, Roben was called away by her New York Dazzle magazine boss to manage to go to Tahiti so as to supervise a fashion event. She had no choice but to offer $\mathbf{\$ 7 0 0}$ for hiring the middle aged pilot Quinn Harris to fly her there in a dilapidated aircraft. Unfortunately, in their flight, they were struck by lightening and had to crash-land on the beach of an unknown island, damaging the landing devices of the craft.So out of touch with everybody, they two had to manage their lives there and then. After a series of misfortunes and mishaps, they forged a romantic relationship over this course, and finally become engaged. Whereas Frank, after a futile search for his fiancee,assuming that she was dead,and persistently courted by the big-breasted Angelica, cultivated their relations and slept with each other. Feeling deeply sorry and sorrowful for his shameful behavior, Frank confessed his guilty conscience to Roben who managed to fly back, but was finally rejected and dumped.This movie features the exotic landscape, picturesque panorama of views and winding action.The writer of the paper holds that it is of great significance and insight to review this film against this current complex backdrop of $21^{\text {st }}$ century. Therefore, he attempts to analyze the movie from the following three perspectives: 1 . the competent, skillful and richly experienced middle-aged man like Quinn is specially favored by young girls, particularly beautiful and elegant ones; 2 . the young and inexperienced man like Frank usually can not stand the temptation and succumb readily to sexy girls like Angelica,hence undependable despite his enormous youth and resilient vitality; 3. by such arrangement of the fates of main characters, the director, in one way or another, has, more or less, the tendency of being a racist, to the writer's mind.
\end{abstract}

Keywords-Tasting Heaven of Time and Space Good-Taster; Six Days and Seven Nights; "Uncle-complex"

\section{INTRODUCTION}

Generally speaking, Six Days and Seven Nights is rated low by professionals in the west. However, there are still some disagreements. Some rank it with The African Queen, Romancing the Stone, My Favorite Wife and Move over Darling. thinking that" a lot of it seems cobbled together out of spare parts." (Roger Ebert.1998.) Consequently, "bright, breezy, thoroughly enjoyable while you're sitting through it yet not likely to stick around in your head for long." (empire online. review) In Rotten Tomatoes website, the film has a rating of $36 \%$ at review aggregation, based on 39 reviews. On Metacritic it holds a score of 51, based on reviews from 23 critics.(wikipedia.org.) Others regard it as a good movie, though not a great one. In search of the greatest movie, you must watch a lot of bad ones finding it." In any case, if you need a quick escape and love flying to beautiful Polynesian Islands loaded with beautiful scenery and good looking people, then his film may be your ticket." (imdb. Storyline). So the writer deems it very significant to review this classic movie.

\section{QUINN, COMPETENT AND CONFIDENT, WARM AND IRRESISTIBLY HANDSOME, REMAINS THE IDEAL UNCLE- COMPLEX MODEL TO RUBEN, A CUTE, AdORABLE AND AMBITIOUS JOURNALIST}

In this movie, Ruben, a high-powered and dainty career woman who works for the New York Elite magazine of Dazzle. She is the beauty of beauties with his blue eyes and blond hair, let alone her slender waist. She is sophisticated, wise cracking and big-city lady. Frank planned this holiday for just love, fun and joy. However, things always turn toward the worse sometimes. Just on the second day of arrival at the destination, Ruben was called away for business photo shoot. So Ruben had no alternative but to offer\$ 700 to hire Quinn, her Uncle- complex pilot to take her there. Unexpectedly, their small plane was stricken by lightening halfway, they had to crash-land on an unknown island, damaging their landing devices of the craft. So they just about manage their survival there. First of all, they had to find some water. On their way, Ruben goes forward but afraid of Quinn's eye-grabbing her body with scanty clothes, so she leads them.In the bush, they encountered a big dark hog, which surprised her enormously, so she jumped quickly into the pond of a waterfall with a rainbow hanging about. Then some sort of snakelike creature, crept into her pants. This time again, Quinn pushed his hand into her pants and grabbed a snake out and thrown it off swiftly. Secondly, they had to search for some food. On this uninhabited island, some peacocks are leisurely staying on the beach. So the resourceful Quinn, disguised him with the leave of palm trees and secretly hunted one and roasted it. Then, when they were climbing a mountain, they fell into a giant hole.Out of it, they found a big scorpion resting on Ruben's head. Quinn swiftly grabbed it and threw it away, thus getting her out of trouble again. One morning, Ruben was woken up by the noise of a plane flying over them, she wasted their only means of securing rescue by firing the only one signal bullet 
and igniting a palm tree, hence no way to be saved. Yet,what's the worst is that, they met some pirates on the sea with whom they went through thick and thin.To their surprise, they managed to discover a Japanese water plane perching in the forest and tried their best to fit the landing device on their own plane.So they finally, with twists and turns,managed to fly back to Makatea. What is commendable is that these two, in the face of their very survival, cursed, quarreled and even fought, but in this process they forged their loving relationship. To put it simply, they are to the point of "if we can't have sex, give us some action." (http://www.flickfilosopher.com/1998/06/) Or it is safe to say that this beauty of Ruben falls unconsciously into the love trap of her uncle-complex Quinn.This is quite for sure.

\section{DESPITE His ENORMOUS VigOR AND VitALITY, FRANK IS YOUNG AND GREEN, THUS UNDEPENDABLE IN LOVE MATTERS}

Now we turn to the antagonist Frank. Originally, he planned to enjoy a wonderful holiday in Hawaii so as to enhance their romance in a secluded tropical paradise which he longs for eagerly.There, he proposed to her and she accepted his ring as a gift. However, due to the dire emergency, he was left in Makatea on his own. You know what? He beguiled himself with the watching the hot, exotic and tempting grass-skirt dances put on by the natives, particularly Angela. After their failed attempt to search and find Roben and Quine, Angela seduced him and he succumbed to her, which he knew it was very bad and totally wrong. Therefore when the natives conducted a ceremonial funeral by the custom of the Hawaiians, just at this time, Roben managed to fly back with the wounded Quine. Of course, Frank, as a pious man, he detailed his wrong-doings with Angela and was rejected by Ruben, Instead, She proposed to Quin, her uncle-complex idol. Subsequently, they got engaged and Frank, out of disappointment, flew back to New York alone.In this miserable and merry holiday, Frank enjoyed the exotic beautiful scenery and tasted the sexy, big-breasted Angela. Nevertheless, to his misfortune, he lost his gorgeous, blond-haired and blue-eyed girlfriend Ruben for he proved to be disloyal.

\section{SUCH AN LAYOUT OF ARRANGEMENTS MANIFESTS THE DIRECTOR'S TENDENCY OF BEING A RACIST IN A CERTAIN SORT OF WAY}

This 1998 film is a loving, romantic, action movie which stars Harrison Ford and Anne Heche and David Schwimmer and was directed by Ivan Reitman. Based on Leone, racism is defined as the belief in inherent superiority of a particular race. It denies the basic equality of humankind and correlates ability with physical composition. Therefore, it reckons that the success in any social endeavor largely depends on genetic endowment rather than environment and access to opportunity. Racism can take on a variety of forms: personal or institutional. Some are almost impossible to detect, while others are blatant or transparent. (Larry A Samovar et al. 2012. p125-126.) In the movie in question, Ivan Reitman deliberately designed the outcome of stars in such a way that the most beautiful Roben (blond-haired and blue-eyed- deemed as the supreme beauty in the white race) matches the most handsome guy Quinn (of the same kind, though faded in a certain sort of way due to his age). That is, her ideal "uncle-complex" idol. However, Frank, Roben's boyfriend, with dark hair and dark eyes, young and robust, was eventually rebuffed by her for he had an affair with the bigbreasted island seductress and masseuse Angelica who was also dark-haired and dark-skinned after being drunk. Do you think that this is a mere coincidence? Or to put it mildly, like seeks like? Obviously, the director is preaching the doctrine that whites ranks the top of human race, while dark races fall naturally back to their own race?! In so doing, it hints at racial separation, if not racial segregation in movies? Or a new kind of racism? Don't you feel the same way?

\section{CONCLUSION}

Despite the low rate of professionals in the west, Six Days and Seven Nights, is, nevertheless, deemed very highly as a very hot and original in the eyes of Chinese. It features exotic, picturesque, and humorous comedy with its arresting sand beach; hit and hot dances; marvelous landscape; stimulating pirates and sexy guys, etc. If you desire a brief escape, an eye feast, and rest and recharge, this movie certainly remains to be a very nice choice. It, no doubt, can enrich your imagination; appreciate the exotic scenery; understand and experience the perfect harmony between nature and nurture, to name only a few. Personally, I enlist this movie at the top list of my favorite films. By means of delivering, discussing and debating movie lectures, I, as an inspiring teacher, witness students' growth and share their pleasure in their psychological well-being, enjoy the beauty and bounty of Hawaii islands, and above all, uplift and raise up their moral integrity, one generation after another.

\section{REFERENCES}

[1] http://baike.baidu.com/link?url=e1M8KLAYApNJ3zzB6b.

[2] http://en.wikiepedia.org/wiki/Six Days, Seven Nights.

[3] https://en.wikipedia.org/wiki/Six days, Seven Nights

[4] http://gohawaii.about.com/od/hawaii media guide/ss/six days seven nights.htm.

[5] http://www.empireonline,com/movies/six-days-seven-nights/review/.

[6] http:www.flickfilosopher.com/1998/06/six-days-seven-nightsreview.html.

[7] http://www.imdb.com/title/tt0120828/.

[8] http://www.rogerebert.com/reviews/six-days-seven-nights-1998.

[9] http://www.themoviescene.co.uk/reviews/six-days-seven-nights/sixdays-seven-nights.html.

[10] Larry A Samovar et al. Cross-Cultural Communication.6th ed. Peking University Press.2012.11.

[11] lipeilongymcn.Six Days Seven Nights Plot. Baidu Library. 